$\begin{array}{ll}\text { Research Square } & \begin{array}{l}\text { Preprints are preliminary reports that have not undergone peer review. } \\ \text { They should not be considered conclusive, used to inform clinical practice, } \\ \text { or referenced by the media as validated information. }\end{array}\end{array}$

\title{
Fertilization Strategies To Improve Crop Yields and N Use Efficiency Depending on Soil pH in Chinese Cabbage-Maize Rotation
}

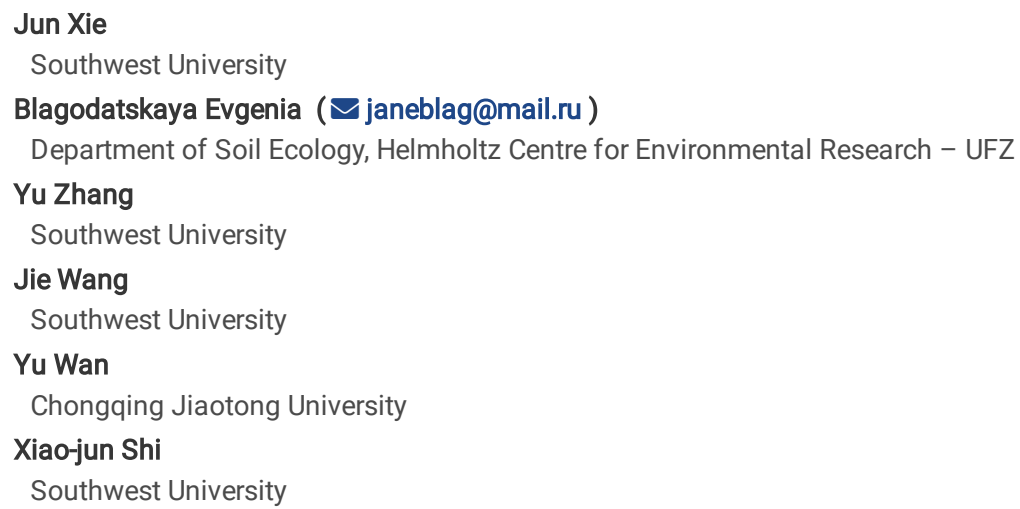

Research Article

Keywords: Chinese cabbage, Maize, $\mathrm{N}$ uptake, $\mathrm{N}$ use efficiency, $\mathrm{N}$ surplus

Posted Date: January 27th, 2022

DOl: https://doi.org/10.21203/rs.3.rs-1278220/v1

License: (c) (i) This work is licensed under a Creative Commons Attribution 4.0 International License. Read Full License 


\section{Abstract}

Aims

The efficiency of fertilizer nitrogen $(\mathrm{N})$ use strongly depends on soil pH and affects both agricultural production and environmental pollution control. However, the effect of soil pH on $\mathrm{N}$ use efficiency (NUE) remains unclear.

\section{Methods}

We compared crop yield, $\mathrm{N}$ uptake, NUE, and the $\mathrm{N}$ input-output balance in a Chinese cabbage-maize cropping system in a field experiment from 2011 to 2016 along a pH gradient (alkaline ( $\mathrm{pH} 8.32)$, near-neutral $(\mathrm{pH} 6.56)$ and acidic soil $(\mathrm{pH} 5.91))$.

\section{Results}

Mineral fertilization had the worst effect in acidic soils, because it significantly decreased soil $\mathrm{pH}$, as well as decreased crop yield, $\mathrm{N}$ uptake, and NUE. Combined chicken manure-mineral fertilization was most favorable irrespective of soil pH because it increased soil quality (e.g., high total $\mathrm{N}$ and organic $\mathrm{C}$ contents) and maintained a neutral soil pH. Chicken manure treatment was most appropriate in acidic soils because it increased $\mathrm{pH}$ by 2.03 units, up to $13 \%$ crop yield, and increased N uptake and NUE than that in alkaline and near-neutral soils. Under manure treatments, the $\mathrm{N}$ surplus was the lowest in acidic soil. Under mineral fertilization, however, the $\mathrm{N}$ surplus in acidic soil was the highest.

\section{Conclusions}

We conclude that combined organic-mineral fertilization in alkaline, near-neutral, and acidic soils is a promising strategy that not only increases the crop yield, $\mathrm{N}$ uptake, and NUE but also decreases the $\mathrm{N}$ surplus. Manure fertilization is also recommended as an efficient strategy in acidic soils to increase crop yield and NUE by improving soil $\mathrm{pH}$.

\section{Highlights}

- Combined organic-mineral increases the yields of both crops in acidic soil.

- Mineral fertilization decreases the yields of both crops in acidic soil.

- Manure treatment increases soil pH by 2.03 units in acidic soil.

- Mineral fertilization decreases soil pH by 1.47 units in acidic soil.

- Manure treatment increases $\mathrm{N}$ uptake and NUE of both crops in acidic soil.

\section{Introduction}

Nitrogen $(\mathrm{N})$ is one of the most important plant nutrients and the most crucial yield limiting factor in agricultural fields (Cassman et al., 2003). This motivates farmers to apply excessive $\mathrm{N}$ to ensure high crop yields (Cui et al., 2008; Zhang et al., 2016). The yield response to applied N, however, tends to decrease gradually when $\mathrm{N}$ application exceeds a certain threshold (Zhu and Chen, 2002). In the long term (i.e., over a decade), excessive $\mathrm{N}$ input without an increase in the crop yield can reduce both the N use efficiency (NUE) and N recovery efficiency (NRE) to values below 30\% (Liu et al., 2008; Yang et al. 2013). Unbalanced fertilizations, involving a high $\mathrm{N}$ input with a low NRE, often results in negative ecological consequences such as air pollution, water eutrophication, and soil degradation (Galloway et al., 2008; Chen et al., 2010; Zhang et al., 2017).

The application of a rational input of mineral $\mathrm{N}$ to increase both crop yield and NUE requires improved $\mathrm{N}$ management practices in agricultural systems. Many existing strategies, such as site-specific $\mathrm{N}$ management, optimum $\mathrm{N}$ application, controlled-release fertilizer, deep placement, and integrated management practices (Xu et al., 2012; Chen et al., 2006; Yang et al., 2012; Yao et al., 2017; Cao et al., 2013), are restricted by their relatively high cost, additional required labor inputs, or the lack of appropriate technology.

Given that organic fertilizers improve soil structure and nutrient content, their application in agriculture is a promising strategy not only to ensure a sustainable yield and high economic benefits (Pan et al., 2009; Ghosh et al., 2012; Mi et al., 2016) but also to reduce the environmental cost of the applied fertilizers (Liu et al., 2016). Simultaneously, a commonly used combination of organic and mineral fertilization has been shown to increase NUE significantly and is easy to apply (Duan et al., 2014; Pan et al., 2009). Generally, the NUE values vary widely from 4-90\% in diverse soil types and different cropping systems (Liu et al., 2010; Zhang et al., 2017; Benbi and Biswas,1997).

A wheat-maize rotation is a popular cropping system in many countries, such as the United States and Canada (Barbaricka et al., 2012; Cociu, 2012); therefore, NUE in such systems is well documented in contrasting soil types, e.g., gray desert soil, fluvo-aquic soil, loessial soil, and red earth (Liu et al., 2010; Duan et al., 2014). However, the effect of soil pH on NUE remains unclear. Chinese cabbage-maize rotation is a double-cropping system widespread in China, and organic materials would improve the yield and quality of crops in Chinese cabbage-maize rotations (Chen et al., 2021). Simultaneously, there is little information about NUE in Chinese cabbage-maize rotations, especially in soils exhibiting different $\mathrm{pH}$ values that belong to the same soil type classification. For this reason, we carried out a six-year field experiment to explore the effects of the replacement of mineral $\mathrm{N}$ with organic $\mathrm{N}$ on Chinese cabbage-maize rotation along a soil pH 
gradient. We hypothesized that improving soil pH would increase crop yield, $\mathrm{N}$ uptake, and NUE, simultaneously decreasing the risk of environmental contamination. Therefore, the objectives of this study were to 1) to determine soil properties under the replacement of mineral $\mathrm{N}$ with organic $\mathrm{N}$ along a soil pH gradient; 2) to estimate the replacement of mineral $\mathrm{N}$ with organic $\mathrm{N}$ along a soil pH gradient for crop yields, NUE, and $\mathrm{N}$ balance; 3 ) to provide better management under Chinese cabbage-maize rotations along a soil pH gradient.

\section{Materials And Methods}

\section{Experimental sites}

The experiment was conducted in 2007 at the experimental station of Southwest University $\left(106^{\circ} 26^{\prime} \mathrm{E}, 30^{\circ} 26^{\prime} \mathrm{N}, 266.3 \mathrm{~m}\right.$ above sea level), Chongqing, China. This region has a subtropical monsoon climate. An automatic weather station was installed in our experimental field to monitor air temperature and precipitation data (Fig. 1). The soil is classified as purple soil (an entisol according to the USDA soil taxonomy). At the beginning of the experiment in 2007, soil properties in $0-20 \mathrm{~cm}$ were as follows: soil pH in alkaline, near-neutral, and acidic soils were $8.32,6.56$, and 5.91, respectively; soil organic carbon content in alkaline, near-neutral, and acidic soils were (in $\mathrm{g} \mathrm{kg}^{-1}$ ) $10.45,9.40$, and 10.73 , respectively; soil total $\mathrm{N}$ content in alkaline, near-neutral, and acidic soils were (in $\mathrm{g} \mathrm{kg}^{-1}$ ) $1.41,0.86$, and 0.82 , respectively.

\section{Experimental design}

The cropping system was vegetable-maize (Zea mays L.) rotation. The vegetable was planted in October and harvested it in January of the following year. Then we planted maize in March and harvested it in August. The vegetable was mustard (Brassica juncea var. tumida) between 2007 and 2010 . Then we replaced mustard with Chinese cabbage (Brassica pekinensis (Lour.) Rupr.) from 2011 to 2016. The application rates of N, P, and K fertilizers were the same at mustard and Chinese cabbage seasons. In the research, we focused on Chinese cabbage-maize rotation from 2011 to 2016.

There were four treatments (three replicates each) applied within each soil pH category in a completely randomized design with a plot size of $1 \mathrm{~m} \times 1.5 \mathrm{~m}$. Each plot was separated by cement to avoid water and nutrient movement between plots. These four treatments were as follows: (1) no-fertilization control (CT); (2) combined mineral N, P and K fertilization (CF); (3) 50\% CF + 50\% chicken manure N (CFM); and (4) chicken manure N (M). Treatments 2 - 4 received the same amounts of $\mathrm{N}$ from the fertilizers. Urea, potassium dihydrogen phosphate, and potassium sulfate were the applied forms of mineral $\mathrm{N}, \mathrm{P}$, and $\mathrm{K}$, and chicken manure $\mathrm{N}$ was applied as organic $\mathrm{N}$. The $\mathrm{C}, \mathrm{N}, \mathrm{P}$, and $\mathrm{K}$ concentrations in chicken manure were (in $\mathrm{g} \mathrm{kg}^{-1}$ ) $359.6,14,30$, and 31 , respectively. Based on the adjustment of mineral fertilizers and organic manure, the same total amounts of $\mathrm{N}, \mathrm{P}$, and K were applied at rates of $480 \mathrm{~kg} \mathrm{~N} \mathrm{ha}^{-1} \mathrm{year}^{-1}, 180 \mathrm{~kg} \mathrm{P}_{2} \mathrm{O}_{5}$ ha $^{-1}$ year ${ }^{-1}$, and $240 \mathrm{~kg} \mathrm{~K}_{2} \mathrm{O} \mathrm{ha}{ }^{-1}$ year $^{-1}$, respectively. During the Chinese cabbage season, the $\mathrm{N}, \mathrm{P}$, and K were applied at rates of $300 \mathrm{~kg} \mathrm{~N}^{-1}$ year ${ }^{-1}, 90 \mathrm{~kg} \mathrm{P}_{2} \mathrm{O}_{5}$ $\mathrm{ha}^{-1}$ year $^{-1}$, and $150 \mathrm{~kg} \mathrm{~K}_{2} \mathrm{O} \mathrm{ha-1}$ year $^{-1}$, respectively. During the maize season, the $\mathrm{N}, \mathrm{P}$, and $\mathrm{K}$ were applied at rates of $180 \mathrm{~kg} \mathrm{~N} \mathrm{ha}^{-1} \mathrm{year}^{-1}, 90 \mathrm{~kg} \mathrm{P}_{2} \mathrm{O}_{5}$ ha $^{-1}$ year $^{-1}$, and $90 \mathrm{~kg} \mathrm{~K}_{2} \mathrm{O}$ ha $^{-1}$ year $^{-1}$, respectively.

\section{Plant and soil sampling and analysis}

The yields of Chinese cabbage and maize grain were calculated by their fresh weight and dry weight, respectively. Plant samples were air-dried, ground, and passed through a $0.15 \mathrm{~mm}$ sieve and analyzed for total $\mathrm{N}$ using the Micro-Kjeldahl method (Page et al., 1982). After maize harvesting, soils from five spots with an "S"-shaped configuration were collected at a 0-20 cm depth in each plot using an auger and pooled into one composite sample. The soil samples were air-dried, ground, and passed through 2.0-mm and 0.25-mm sieves. Soil physicochemical properties, including pH, total nitrogen (TN), and organic carbon (SOC) content, were measured using conventional methods (Cheng et al., 2019; Li et al., 2016).

\section{N-based physiological indexes}

We estimated the $\mathrm{N}$ agronomic efficiency (AEN), partial factor productivity (PFP), $\mathrm{N}$ physiological efficiency (NPE), and apparent accumulated $\mathrm{N}$ recovery efficiency (NREac) to illustrate the N use efficiency (Novoa and Loomis, 1981; Jin et al., 2012; Hartmann et al., 2015; Liu et al., 2010). These parameters were calculated as follows:

$\mathrm{AEN}=\left(\mathrm{Y}-\mathrm{Y}_{0}\right) / \mathrm{F}$

$\mathrm{PFP}=\mathrm{Y} / \mathrm{F}$

$\mathrm{NPE}=\left(\mathrm{Y}-\mathrm{Y}_{0}\right) /\left(\mathrm{TP}_{\mathrm{N}^{-}}-\mathrm{TP} \mathrm{P}_{0}\right)$

$\mathrm{NREac}=\sum_{\mathrm{i}}^{\mathrm{n}}(\mathrm{U}-\mathrm{U} 0) / \sum_{\mathrm{i}}^{\mathrm{n}} \mathrm{Ur}$

where $\mathrm{TP}_{\mathrm{N}}$ and $\mathrm{TP}_{0}$ are the total $\mathrm{N}$ uptake of plants with and without $\mathrm{N}$ application $\left(\mathrm{kg} \mathrm{N} \mathrm{ha}^{-1}\right), \mathrm{Y}$ and $\mathrm{Y}_{0}$ are the crop yields with and without $\mathrm{N}$ application (kg $\left.\mathrm{ha}^{-1}\right), \mathrm{U}$ and $\mathrm{U} 0$ are the total $\mathrm{N}$ uptake by crops with and without $\mathrm{N}$ application $\left(\mathrm{kg} \mathrm{N} \mathrm{ha}^{-1}\right), \mathrm{F}$ is the amount of $\mathrm{N}$ fertilizer applied $\left(\mathrm{kg} \mathrm{N}^{-1}\right)$, Ur is the amount of $\mathrm{N}$ applied $\left(\mathrm{kg} \mathrm{N} \mathrm{ha}^{-1}\right)$, and $\mathrm{i}$ is the number of cultivation years (6 years in the present study). $\mathrm{N}$ surplus was defined as total $\mathrm{N}$ application rate from chicken manure and mineral fertilizer minus crop aboveground $\mathrm{N}$ uptake for the whole growing season (Liu et al., 2010).

\section{Statistical analyses}


All statistical analyses were carried out with SPSS 16.0 (SPSS Inc., 2007). We used one-way ANOVA to test the differences at $P<0.05$ between treatments and soils.

\section{Results}

\section{Soil properties}

Compared to the mineral fertilization, manure treatments significantly increased soil pH in near-neutral and acidic soils (Table 1). The soil organic carbon and soil total $\mathrm{N}$ contents under fertilization increased by $11.1-134 \%$ and $14.4-325.8 \%$ as compared to the no-fertilization treatment. The soil organic carbon and soil total $\mathrm{N}$ contents under manure treatments increased than mineral fertilization irrespective of the soil pH. Moreover, soil pH, organic carbon, and total $\mathrm{N}$ under fertilization in alkaline soil were higher than in near-neutral and acidic soils.

Table 1

Soil properties in 2017. Data (means, $n=3)$ followed by different letters represent significant differences $(P<0.05)$ among different fertilizations for the same soil in columns $(a, b, c, d)$ and among different $\mathrm{pH}$ soils for the same fertilization in rows $(x, y, z)$.

\begin{tabular}{|c|c|c|c|c|c|c|c|c|c|}
\hline \multirow[t]{2}{*}{ Treatments※ } & \multicolumn{3}{|l|}{ Soil pH } & \multicolumn{3}{|c|}{ Soil organic carbon $\left(\mathrm{g} \mathrm{kg}^{-1}\right)$} & \multicolumn{3}{|c|}{ Soil total $\mathrm{N}\left(\mathrm{g} \mathrm{kg}^{-1}\right)$} \\
\hline & Alkaline & $\begin{array}{l}\text { Near- } \\
\text { neutral }\end{array}$ & Acidic & Alkaline & $\begin{array}{l}\text { Near- } \\
\text { neutral }\end{array}$ & Acidic & Alkaline & $\begin{array}{l}\text { Near- } \\
\text { neutral }\end{array}$ & Acidic \\
\hline CT & $\begin{array}{l}8.24 \pm 0.03 \\
a, x\end{array}$ & $\begin{array}{l}6.40 \pm 0.02 \\
b, y\end{array}$ & $\begin{array}{l}5.73 \pm 0.05 \\
b, z\end{array}$ & $\begin{array}{l}9.85 \pm 0.03 \\
d, x\end{array}$ & $\begin{array}{l}8.54 \pm 0.21 d \\
y\end{array}$ & $\begin{array}{l}7.47 \pm 0.13 \\
c, z\end{array}$ & $\begin{array}{l}1.18 \pm 0.11 \\
c, x\end{array}$ & $\begin{array}{l}0.66 \pm 0.06 \\
d, y\end{array}$ & $\begin{array}{l}0.59 \pm 0.01 \\
d, y\end{array}$ \\
\hline $\mathrm{CF}$ & $\begin{array}{l}7.90 \pm 0.09 \\
b, x\end{array}$ & $\begin{array}{l}4.50 \pm 0.12 \\
c, y\end{array}$ & $\begin{array}{l}4.02 \pm 0.19 \\
c, z\end{array}$ & $\begin{array}{l}11.27 \pm 0.28 \\
c, x\end{array}$ & $\begin{array}{l}10.93 \pm 0.02 \\
c, x\end{array}$ & $\begin{array}{l}8.30 \pm 0.49 \\
c, y\end{array}$ & $\begin{array}{l}1.35 \pm 0.04 \\
c, x\end{array}$ & $\begin{array}{l}1.23 \pm 0.04 \\
c, y\end{array}$ & $\begin{array}{l}1.13 \pm 0.04 \\
c, z\end{array}$ \\
\hline CFM & $\begin{array}{l}7.89 \pm 0.07 \\
b, x\end{array}$ & $\begin{array}{l}7.35 \pm 0.13 \\
a, y\end{array}$ & $\begin{array}{l}7.42 \pm 0.02 \\
a, y\end{array}$ & $\begin{array}{l}15.01 \pm 1.17 \\
b, x\end{array}$ & $\begin{array}{l}13.83 \pm 0.27 \\
b, x\end{array}$ & $\begin{array}{l}10.95 \pm 0.35 \\
b, y\end{array}$ & $\begin{array}{l}2.25 \pm 0.10 \\
b, x\end{array}$ & $\begin{array}{l}1.95 \pm 0.10 \\
b, y\end{array}$ & $\begin{array}{l}1.65 \pm 0.09 \\
b, z\end{array}$ \\
\hline M & $\begin{array}{l}7.90 \pm 0.04 \\
b, x\end{array}$ & $\begin{array}{l}7.42 \pm 0.04 \\
a, z\end{array}$ & $\begin{array}{l}7.52 \pm 0.04 \\
a, y\end{array}$ & $\begin{array}{l}20.28 \pm 0.74 \\
a, x\end{array}$ & $\begin{array}{l}19.98 \pm 0.49 \\
a, x\end{array}$ & $\begin{array}{l}15.80 \pm 1.97 \\
a, y\end{array}$ & $\begin{array}{l}3.04 \pm 0.10 \\
a, x\end{array}$ & $\begin{array}{l}2.81 \pm 0.10 \\
a, x\end{array}$ & $\begin{array}{l}2.40 \pm 0.15 \\
a, y\end{array}$ \\
\hline
\end{tabular}

\section{Soil pH change}

Soil pH change under manure treatments increased in near-neutral and acidic soils compared to alkaline soil (Fig. 2). In contrast, under mineral fertilization, soil $\mathrm{pH}$ change decreased in near-neutral and acidic soils than alkaline soil. Relative to the alkaline and near-neutral soils, soil pH change in acidic soil increased up to 2.03 units under manure treatments. However, soil pH change in near-neutral and acidic soils decreased by 1.64 and 1.47 units under mineral fertilization than in alkaline soil.

\section{Crop yield}

Fertilization generally increased the cabbage yield by 58.7 - 291.7\% compared to no-fertilization treatment over the six studied years (Fig. 3). The effect of mineral fertilization was the lowest, while no differences were observed under manure treatments in alkaline and near-neutral soils (Table 2). The cabbage yield under combined organic-mineral fertilization increased by $7.9 \%$ than manure fertilization in acidic soil. Compared to the effect of mineral fertilization in alkaline and near-neutral soils, mineral fertilization in acidic soil decreased the cabbage yield up to $42.1 \%$. Relative to the combined organic-mineral fertilization in acidic soil, the cabbage yield under combined organic-mineral fertilization in alkaline and near-neutral soils decreased up to $15.9 \%$. Compared to the effect of manure fertilization in near-neutral and acidic soils, the cabbage yield in alkaline soil under manure fertilization decreased by $7.8 \%$ and $11.1 \%$, respectively. 
Table 2

The average yield of Chinese cabbage and maize over 6 years $\left(\mathrm{t} \mathrm{ha} \mathrm{A}^{-1}\right)$. Data (means, $\left.n=3\right)$ followed by different letters represent significant differences $(P<$ $0.05)$ among different fertilizations for the same soil in columns $(a, b, c, d)$ and among different $\mathrm{pH}$ soils for the same fertilization in rows ( $x, y, z)$.

\begin{tabular}{|c|c|c|c|c|c|c|c|c|c|}
\hline \multirow[t]{3}{*}{ Treatments※ } & \multirow{2}{*}{\multicolumn{3}{|c|}{ Chinese cabbage }} & \multicolumn{6}{|l|}{ Maize } \\
\hline & & & & \multicolumn{3}{|l|}{ Grain } & \multicolumn{3}{|c|}{ Aboveground biomass } \\
\hline & Alkaline & $\begin{array}{l}\text { Near- } \\
\text { neutral }\end{array}$ & Acidic & Alkaline & $\begin{array}{l}\text { Near- } \\
\text { neutral }\end{array}$ & Acidic & Alkaline & Near-neutral & Acidic \\
\hline CT & $\begin{array}{l}28.0 \pm 2.7 \mathrm{c}, \\
x\end{array}$ & $\begin{array}{l}25.7 \pm 0.5 c \text {, } \\
x\end{array}$ & $\begin{array}{l}20.6 \pm 2.2 d, \\
y\end{array}$ & $\begin{array}{l}4.3 \pm 0.3 c \\
x\end{array}$ & $\begin{array}{l}4.1 \pm 0.1 \mathrm{c} \\
\mathrm{x}\end{array}$ & $\begin{array}{l}3.0 \pm 0.1 d, \\
y\end{array}$ & $8.6 \pm 0.5 c, x$ & $8.3 \pm 0.4 \mathrm{c}, \mathrm{x}$ & $6.4 \pm 0.1 \mathrm{~d}, \mathrm{y}$ \\
\hline $\mathrm{CF}$ & $\begin{array}{l}56.5 \pm 1.7 b \\
x\end{array}$ & $\begin{array}{l}52.6 \pm 3.5 b \\
x\end{array}$ & $\begin{array}{l}32.7 \pm 2.1 \mathrm{c}, \\
\mathrm{y}\end{array}$ & $\begin{array}{l}9.8 \pm 0.2 a \\
x\end{array}$ & $\begin{array}{l}9.5 \pm 0.3 a b \\
x\end{array}$ & $\begin{array}{l}7.3 \pm 0.4 c \\
y\end{array}$ & $\begin{array}{l}19.1 \pm 0.2 a b \\
x\end{array}$ & $\begin{array}{l}18.3 \pm 0.6 \mathrm{ab} \\
\mathrm{x}\end{array}$ & $\begin{array}{l}15.2 \pm 1.1 \mathrm{c}, \\
\mathrm{y}\end{array}$ \\
\hline CFM & $\begin{array}{l}67.9 \pm 2.0 \mathrm{a}, \\
\mathrm{z}\end{array}$ & $\begin{array}{l}74.1 \pm 1.7 a, \\
y\end{array}$ & $\begin{array}{l}80.7 \pm 1.7 a, \\
x\end{array}$ & $\begin{array}{l}9.9 \pm 0.3 a, \\
y\end{array}$ & $\begin{array}{l}10.1 \pm 0.7 a \\
y\end{array}$ & $\begin{array}{l}11.1 \pm 0.1 \mathrm{a}, \\
\mathrm{x}\end{array}$ & 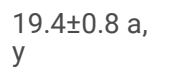 & $\begin{array}{l}19.6 \pm 1.1 \mathrm{a} \\
\mathrm{y}\end{array}$ & $\begin{array}{l}21.9 \pm 0.4 a, \\
x\end{array}$ \\
\hline M & $\begin{array}{l}66.5 \pm 2.4 a, \\
y\end{array}$ & $\begin{array}{l}72.1 \pm 1.2 \mathrm{a}, \\
\mathrm{x}\end{array}$ & $\begin{array}{l}74.8 \pm 1.1 b \text {, } \\
x\end{array}$ & $\begin{array}{l}8.7 \pm 0.8 b \\
y\end{array}$ & $\begin{array}{l}9.0 \pm 0.6 \mathrm{~b}, \\
\mathrm{y}\end{array}$ & $\begin{array}{l}10.2 \pm 0.1 \mathrm{~b}, \\
\mathrm{x}\end{array}$ & $\begin{array}{l}17.5 \pm 1.6 b \\
y\end{array}$ & $\begin{array}{l}17.8 \pm 0.7 b \\
x y\end{array}$ & $\begin{array}{l}19.8 \pm 0.4 b \text {, } \\
x\end{array}$ \\
\hline
\end{tabular}

※Abbreviation in treatments represented no-fertilization control (CT), combined chemical N, $\mathrm{P}$ and $\mathrm{K}$ fertilization (CF), 50\% CF+50\% chicken manure $\mathrm{N}$ (CFM), chicken manure $\mathrm{N}(\mathrm{M})$, respectively.

Maize grain yield and aboveground biomass fluctuated with the fertilization years along the pH gradient (Fig. 4). Fertilization improved the grain yield of maize by $102.3-270 \%$. The effect of manure fertilization was the lowest in alkaline soil, while the effect of mineral fertilization was the weakest in acidic soil (Table 2). The maize grain yield under combined organic-mineral fertilization increased by $12.2 \%$ than manure fertilization in near-neutral soil. Moreover, maize grain yield had no differences between mineral fertilization and manure fertilization in near-neutral soil. Relative to mineral fertilization in alkaline and nearneutral soils, mineral fertilization in acidic soil decreased the maize grain yield up to $25.5 \%$. Compared to manure treatments in acidic soil, the maize grain yield under manure treatment in alkaline and near-neutral soils decreased by $9.0-14.7 \%$.

For maize aboveground biomass, fertilization enhanced the maize aboveground biomass by $103.5-242.2 \%$. Compared to manure fertilization, combined organic-mineral fertilization increased the maize aboveground biomass up to $10.9 \%$ irrespective of soil pH. The effect of mineral fertilization was the lowest in acidic soil. Relative to mineral fertilization in acidic soil, mineral fertilization in alkaline and near-neutral soil increased the maize aboveground biomass by $25.7 \%$ and $20.4 \%$, respectively. Compared to manure treatments in alkaline soil, manure treatments in acidic soil significantly increased the aboveground maize biomass.

\section{N uptake}

Combined organic-mineral fertilization had the strongest effect on $\mathrm{N}$ uptake by Chinese cabbage (Table 3 ). Under mineral fertilization, $\mathrm{N}$ uptake in acidic soil was decreased up to $31.9 \%$ compared to that in alkaline and near-neutral soils. Under manure treatments, $\mathrm{N}$ uptake in acidic soil increased up to $8.2 \%$ than that in alkaline soil.

Table 3

The averages of $\mathrm{N}$ uptake in response to different fertilization across 6 years. Data (means, $n=3$ ) followed by different letters represent significant differences $(P<0.05)$ among different fertilizations for the same soil in columns $(a, b, c, d)$ and among different pH soils for the same fertilization in rows $(x, y, z)$.

\begin{tabular}{|c|c|c|c|c|c|c|c|c|c|}
\hline \multirow[t]{3}{*}{ Treatments※ } & \multirow{2}{*}{\multicolumn{3}{|c|}{ Chinese cabbage }} & \multicolumn{6}{|l|}{ Maize } \\
\hline & & & & \multicolumn{3}{|l|}{ Grain } & \multicolumn{3}{|c|}{ Aboveground } \\
\hline & Alkaline & $\begin{array}{l}\text { Near- } \\
\text { neutral }\end{array}$ & Acidic & Alkaline & $\begin{array}{l}\text { Near- } \\
\text { neutral }\end{array}$ & Acidic & Alkaline & Near-neutral & Acidic \\
\hline CT & $\begin{array}{l}43.8 \pm 2.4 \\
d, x\end{array}$ & $\begin{array}{l}42.4 \pm 0.5 d \\
x\end{array}$ & $\begin{array}{l}38.5 \pm 2.0 \\
\text { d, } y\end{array}$ & $\begin{array}{l}44.4 \pm 4.6 \\
c, x\end{array}$ & $\begin{array}{l}43.4 \pm 0.5 \mathrm{c} \\
\mathrm{x}\end{array}$ & $\begin{array}{l}31.3 \pm 1.4 \\
d, y\end{array}$ & $\begin{array}{l}65.9 \pm 4.9 \mathrm{c}, \\
\mathrm{x}\end{array}$ & $64.7 \pm 1.0 \mathrm{c}, \mathrm{x}$ & $\begin{array}{l}48.9 \pm 2.2 \\
d, y\end{array}$ \\
\hline $\mathrm{CF}$ & $\begin{array}{l}108.8 \pm 1.2 \\
C, x\end{array}$ & $\begin{array}{l}106.3 \pm 4.7 \\
c, x\end{array}$ & $\begin{array}{l}74.1 \pm 6.2 c \\
y\end{array}$ & $\begin{array}{l}136.4 \pm 1.1 \\
a, x\end{array}$ & $\begin{array}{l}134.1 \pm 6.8 \\
a, x\end{array}$ & $\begin{array}{l}109.0 \pm 6.9 \\
c, y\end{array}$ & $\begin{array}{l}213.2 \pm 2.1 \\
a, x\end{array}$ & $\begin{array}{l}209.2 \pm 13.8 \\
a, x\end{array}$ & $\begin{array}{l}167.7 \pm 9.5 \\
c, y\end{array}$ \\
\hline CFM & $\begin{array}{l}122.0 \pm 3.6 \\
a, y\end{array}$ & $\begin{array}{l}127.8 \pm 4.8 \\
a, x y\end{array}$ & $\begin{array}{l}132.0 \pm 1.2 \\
a, x\end{array}$ & $\begin{array}{l}138.9 \pm 3.3 \\
a, y\end{array}$ & $\begin{array}{l}141.3 \pm 9.7 \\
a, x y\end{array}$ & $\begin{array}{l}152.1 \pm 2.3 \\
a, x\end{array}$ & $\begin{array}{l}216.2 \pm 5.3 \\
a, y\end{array}$ & $\begin{array}{l}219.5 \pm 12.3 \\
a, x y\end{array}$ & $\begin{array}{l}235.8 \pm 5.2 \\
a, x\end{array}$ \\
\hline M & $\begin{array}{l}113.6 \pm 1.4 \\
b, y\end{array}$ & $\begin{array}{l}118.1 \pm 4.8 \\
b, x y\end{array}$ & $\begin{array}{l}121.2 \pm 3.6 \\
b, x\end{array}$ & $\begin{array}{l}107.3 \pm 8.1 \\
b, y\end{array}$ & $\begin{array}{l}109.3 \pm 11.1 \\
b, y\end{array}$ & $\begin{array}{l}133.8 \pm 1.6 \\
b, x\end{array}$ & $\begin{array}{l}162.5 \pm 11.6 \\
\text { b, y }\end{array}$ & $\begin{array}{l}166.1 \pm 8.8 b \\
y\end{array}$ & $\begin{array}{l}194.3 \pm 4.0 \\
b, x\end{array}$ \\
\hline
\end{tabular}


Fertilization generally increased the $\mathrm{N}$ uptake in maize grain by $141.7-385.9 \%$ as compared to no-fertilization treatment (Table 3 ). Compared to manure fertilization, combined organic-mineral fertilization significantly increased $\mathrm{N}$ uptake in maize grain irrespective of soil pH. Simultaneously, $\mathrm{N}$ uptake in maize grain had no differences between combined organic-mineral fertilization and mineral fertilization in alkaline and near-neutral soils. Relative to the mineral fertilization in acidic soil, manure treatments increased $\mathrm{N}$ uptake in maize grain up to $39.5 \%$. Under mineral fertilization, maize grain $\mathrm{N}$ uptake in acidic soil decreased up to $20.1 \%$ compared to that in alkaline and near-neutral soils. Under manure treatments, maize grain $\mathrm{N}$ uptake in acidic soil significantly increased than that in alkaline soil.

Fertilization increased $\mathrm{N}$ incorporation in maize aboveground compared to no-fertilization treatment (Table 3 ). Relative to manure fertilization, combined organic-mineral fertilization significantly increased $\mathrm{N}$ uptake in maize aboveground irrespective of soil pH. Moreover, $\mathrm{N}$ uptake in maize aboveground had no differences between combined organic-mineral fertilization and mineral fertilization in alkaline and near-neutral soils. Compared to the mineral fertilization in acidic soil, manure treatments increased $\mathrm{N}$ uptake in maize aboveground up to $40.6 \%$. Under mineral fertilization, maize aboveground $\mathrm{N}$ uptake in alkaline and near-neutral soils increased up to $27.1 \%$ compared to that in acidic soil. In contrast, maize aboveground $\mathrm{N}$ uptake in acidic soil significantly increased under manure treatments than in alkaline soil.

\section{Nitrogen use efficiency}

For Chinese cabbage, manure treatments increased AEN and PFP compared to mineral fertilization irrespective of soil pH (Table 4). Moreover, manure treatments increased NPE than mineral fertilization in near-neutral and acidic soils. Simultaneously, manure fertilization increased NPE by $23.6 \%$ than mineral fertilization in alkaline soil. Under mineral fertilization, AEN and PFP in alkaline and near-neutral soils increased up to $135.1 \%$ and $72.9 \%$ than that in acidic soil. Under manure treatments, AEN, PFP, and NPE in acidic soil significantly increased than that in alkaline soil.

Table 4

$\mathrm{N}$ agronomic efficiency (AEN), partial factor productivity (PFP), and N physiological efficiency (NPE) in Chinese cabbage and maize across 6 years. Data (mear followed by different letters represent significant differences $(P<0.05)$ among treatments for the same soil in columns $(a, b, c, d)$ and different pH soils for th fertilization in rows $(x, y, z)$.

\begin{tabular}{|c|c|c|c|c|c|c|c|c|c|c|}
\hline \multirow[t]{2}{*}{ Crops } & \multirow[t]{2}{*}{ Treatments※ } & \multicolumn{3}{|c|}{ AEN $\left(\mathrm{kg} \mathrm{kg}^{-1}\right)$} & \multicolumn{3}{|c|}{ PFP $\left(\mathrm{kg} \mathrm{kg}^{-1}\right)$} & \multicolumn{3}{|c|}{ NPE $\left(\mathrm{kg} \mathrm{kg}^{-1}\right)$} \\
\hline & & Alkaline & $\begin{array}{l}\text { Near- } \\
\text { neutral }\end{array}$ & Acidic & Alkaline & $\begin{array}{l}\text { Near- } \\
\text { neutral }\end{array}$ & Acidic & Alkaline & $\begin{array}{l}\text { Near- } \\
\text { neutral }\end{array}$ & Acidiı \\
\hline \multirow{3}{*}{$\begin{array}{l}\text { Chinese } \\
\text { cabbage }\end{array}$} & $\mathrm{CF}$ & $\begin{array}{l}95.0 \pm 6.6 \mathrm{~b}, \\
\mathrm{x}\end{array}$ & $\begin{array}{l}89.6 \pm 9.9 \\
b, x\end{array}$ & $\begin{array}{l}40.4 \pm 4.2 \mathrm{c} \\
\mathrm{y}\end{array}$ & $\begin{array}{l}188.3 \pm 5.8 \\
b, x\end{array}$ & $\begin{array}{l}175.3 \pm 11.7 \\
b, x\end{array}$ & $\begin{array}{l}108.9 \pm 7.1 \\
c, y\end{array}$ & $\begin{array}{l}457.6 \pm 13.6 \\
b, x\end{array}$ & $\begin{array}{l}447.4 \pm 53.7 \\
b, x\end{array}$ & $\begin{array}{l}419.3 \\
b, x\end{array}$ \\
\hline & CFM & $\begin{array}{l}132.9 \pm 15.1 \\
a, z\end{array}$ & $\begin{array}{l}161.2 \pm 5.0 \\
\text { a, y }\end{array}$ & $\begin{array}{l}200.5 \pm 9.9 \\
a, x\end{array}$ & $\begin{array}{l}226.2 \pm 6.8 \\
a, z\end{array}$ & $\begin{array}{l}246.9 \pm 5.6 \\
a, y\end{array}$ & $\begin{array}{l}269.0 \pm 5.8 \\
a, x\end{array}$ & $\begin{array}{l}535.4 \pm 46.3 \\
a b, y\end{array}$ & $\begin{array}{l}588.0 \pm 31.8 \\
a, x y\end{array}$ & $\begin{array}{l}651.5 \\
a, x\end{array}$ \\
\hline & $M$ & $\begin{array}{l}128.5 \pm 11.9 \\
a, z\end{array}$ & $\begin{array}{l}154.6 \pm 4.0 \\
a, y\end{array}$ & $\begin{array}{l}180.7 \pm 11.1 \\
b, x\end{array}$ & $\begin{array}{l}221.8 \pm 7.9 \\
a, y\end{array}$ & $\begin{array}{l}240.4 \pm 4.0 \\
a, x\end{array}$ & $\begin{array}{l}249.3 \pm 3.7 \\
b, x\end{array}$ & $\begin{array}{l}565.4 \pm 56.4 \\
a, y\end{array}$ & $\begin{array}{l}649.2 \pm 66.7 \\
a, x y\end{array}$ & $\begin{array}{l}665 . \epsilon \\
a, x\end{array}$ \\
\hline \multirow[t]{3}{*}{ Maize } & $\mathrm{CF}$ & $\begin{array}{l}30.6 \pm 0.9 a, \\
x\end{array}$ & $\begin{array}{l}29.6 \pm 2.6 \\
a, x\end{array}$ & $\begin{array}{l}23.7 \pm 2.3 c \text {, } \\
y\end{array}$ & $\begin{array}{l}54.3 \pm 0.9 \\
a, x\end{array}$ & $\begin{array}{l}52.5 \pm 1.8 \mathrm{a}, \\
\mathrm{x}\end{array}$ & $\begin{array}{l}40.4 \pm 2.5 \\
c, y\end{array}$ & $\begin{array}{l}37.2 \pm 1.1 b \\
x\end{array}$ & $\begin{array}{l}35.5 \pm 0.8 b, \\
x\end{array}$ & $35.0 \pm$ \\
\hline & CFM & $\begin{array}{l}31.4 \pm 3.1 \mathrm{a}, \\
\mathrm{y}\end{array}$ & $\begin{array}{l}33.1 \pm 4.3 \\
a, y\end{array}$ & $\begin{array}{l}45.1 \pm 1.0 \mathrm{a}, \\
\mathrm{x}\end{array}$ & $\begin{array}{l}55.0 \pm 1.6 \\
a, y\end{array}$ & $\begin{array}{l}56.1 \pm 3.8 \mathrm{a} \\
\mathrm{y}\end{array}$ & $\begin{array}{l}61.8 \pm 0.8 \\
a, x\end{array}$ & $\begin{array}{l}37.7 \pm 1.3 b \\
y\end{array}$ & $\begin{array}{l}37.9 \pm 3.0 \mathrm{~b} \\
\mathrm{y}\end{array}$ & $\begin{array}{l}45.7 \pm \\
x\end{array}$ \\
\hline & M & $\begin{array}{l}24.9 \pm 6.0 a, \\
y\end{array}$ & $\begin{array}{l}27.3 \pm 4.0 \\
a, y\end{array}$ & $\begin{array}{l}40.0 \pm 0.3 b \\
x\end{array}$ & $\begin{array}{l}48.6 \pm 4.3 \\
b, y\end{array}$ & $\begin{array}{l}50.3 \pm 3.2 a \\
y\end{array}$ & $\begin{array}{l}56.7 \pm 0.7 \\
b, x\end{array}$ & $\begin{array}{l}46.8 \pm 3.8 \mathrm{a}, \\
x\end{array}$ & $\begin{array}{l}48.1 \pm 6.4 a, \\
x\end{array}$ & $\begin{array}{l}50.4 \pm \\
x\end{array}$ \\
\hline
\end{tabular}

※Abbreviation in treatments represented no-fertilization control (CT), combined chemical N, P and K fertilization (CF), 50\% CF+50\% chicken manure N (CFM), chicken manure $\mathrm{N}(\mathrm{M})$, respectively.

For maize, manure treatments increased AEN, PFP, and NPE than mineral fertilization in acidic soil (Table 4). Moreover, manure fertilization increased NPE up to $25.8 \%$ and $35.5 \%$ compared to mineral fertilization and combined organic-mineral fertilization in alkaline and near-neutral soils. Under mineral fertilization, AEN and PFP in alkaline and near-neutral soils increased up to $29.1 \%$ and $34.4 \%$ than that in acidic soil. Under manure treatments, AEN and PFP in acidic soil significantly increased than that in alkaline and near-neutral soils. Simultaneously, NPE under combined organic-mineral fertilization in acidic soil increased by $21.2 \%$ and $20.6 \%$ than that in alkaline and near-neutral soils.

\section{$\mathrm{N}$ input-output balance and recovery efficiency}

Fertilization generally increased the mean annual $\mathrm{N}$ uptake by 151.6 - 320.7\% (Table 5). Combined organic-mineral fertilization had the strongest effect on mean annual $\mathrm{N}$ uptake. Manure fertilizer decreased mean annual $\mathrm{N}$ uptake compared to mineral fertilizer in alkaline and near-neutral soils but increased this parameter in acidic soil. Under mineral fertilization, mean annual N uptake in alkaline and near-neutral soils increased by $33.2 \%$ and $30.5 \%$ than that in acidic soil. In contrast, the mean annual $\mathrm{N}$ uptake in acidic soil significantly increased compared with that in alkaline soil under manure treatments. 
Table 5

The $\mathrm{N}$ balance of the plow layer at three different soils (the value of crop uptake and $\mathrm{N}$ surplus were averaged over 6 years. Data (means, $n=3$ ) followed by different letters represent significant differences $(P<0.05)$ among different fertilizations for the same soil in columns $(a, b, c, d)$ and among different pH soils for the same fertilization in rows $(x, y, z)$.

\begin{tabular}{|c|c|c|c|c|c|c|c|c|c|}
\hline \multirow[t]{2}{*}{ Treatments※ } & \multicolumn{3}{|c|}{ N uptake $\left(\mathrm{kg} \mathrm{ha}^{-1}\right.$ year $\left.^{-1}\right)$} & \multicolumn{3}{|c|}{$\mathrm{N}$ surplus $\left(\mathrm{kg} \mathrm{ha}^{-1}\right.$ year $\left.^{-1}\right)$} & \multicolumn{3}{|c|}{ NREac (\%) } \\
\hline & Alkaline & Near-neutral & Acidic & Alkaline & Near-neutral & Acidic & Alkaline & $\begin{array}{l}\text { Near- } \\
\text { neutral }\end{array}$ & Acidic \\
\hline CT & $\begin{array}{l}109.7 \pm 7.3 \\
d, x\end{array}$ & $\begin{array}{l}107.1 \pm 1.4 \mathrm{~d} \\
\mathrm{x}\end{array}$ & $\begin{array}{l}87.4 \pm 0.2 d, \\
y\end{array}$ & $\begin{array}{l}-109.7 \pm 7.3 \\
d, y\end{array}$ & $\begin{array}{l}-107.1 \pm 1.4 d \\
y\end{array}$ & $\begin{array}{l}-87.4 \pm 0.2 \\
d, x\end{array}$ & - & - & - \\
\hline $\mathrm{CF}$ & $\begin{array}{l}322.0 \pm 3.3 \\
b, x\end{array}$ & $\begin{array}{l}315.5 \pm 17.7 \\
b, x\end{array}$ & $\begin{array}{l}241.8 \pm 5.9 \\
c, y\end{array}$ & $\begin{array}{l}158.0 \pm 3.3 \\
b, y\end{array}$ & $\begin{array}{l}164.5 \pm 17.7 \\
b, y\end{array}$ & $\begin{array}{l}238.2 \pm 5.9 \\
a, x\end{array}$ & $\begin{array}{l}44.2 \pm 2.2 \\
a, x\end{array}$ & $\begin{array}{l}43.4 \pm 3.7 \\
b, x\end{array}$ & $\begin{array}{l}32.2 \pm 1.2 \\
c, y\end{array}$ \\
\hline CFM & $\begin{array}{l}338.3 \pm 8.8 \\
a, y\end{array}$ & $\begin{array}{l}347.3 \pm 16.5 \\
a, x y\end{array}$ & $\begin{array}{l}367.7 \pm 4.5 \\
a, x\end{array}$ & $\begin{array}{l}141.7 \pm 8.8 \\
c, x\end{array}$ & $\begin{array}{l}132.7 \pm 16.5 \\
c, x y\end{array}$ & $\begin{array}{l}112.3 \pm 4.5 \\
c, y\end{array}$ & $\begin{array}{l}47.6 \pm 3.1 \\
a, y\end{array}$ & $\begin{array}{l}50.0 \pm 3.3 \\
a, y\end{array}$ & $\begin{array}{l}58.4 \pm 1.0 \\
a, x\end{array}$ \\
\hline M & $\begin{array}{l}276.0 \pm 10.3 \\
c, y\end{array}$ & $\begin{array}{l}284.2 \pm 11.3 \\
c, y\end{array}$ & $\begin{array}{l}315.4 \pm 4.3 \\
b, x\end{array}$ & $\begin{array}{l}204.0 \pm 10.3 \\
a, x\end{array}$ & $\begin{array}{l}195.8 \pm 11.3 \\
a, x\end{array}$ & $\begin{array}{l}164.6 \pm 4.3 \\
b, y\end{array}$ & $\begin{array}{l}34.7 \pm 3.7 \\
b, y\end{array}$ & $\begin{array}{l}36.9 \pm 2.4 \\
c, y\end{array}$ & $\begin{array}{l}47.5 \pm 0.9 \\
b, x\end{array}$ \\
\hline
\end{tabular}

Combined organic-mineral fertilization decreased the $\mathrm{N}$ surplus irrespective of soil $\mathrm{pH}$. Manure fertilization increased the $\mathrm{N}$ surplus observed than mineral fertilization in alkaline and near-neutral soils but decreased the $\mathrm{N}$ surplus in acidic soil. The $\mathrm{N}$ surplus under mineral fertilization in acidic soil was increased up to $50.8 \%$ compared with that in alkaline and near-neutral soils. In contrast, the $\mathrm{N}$ surplus under manure treatments in acidic soil significantly decreased than that in alkaline soil.

Combined organic-mineral fertilization and mineral fertilization increased NREac up to $12.9 \%$ than manure fertilization in alkaline soil. Moreover, combined organic-mineral fertilization significantly increased NREac compared to mineral fertilization and manure fertilization in near-neutral and acidic soils. Manure fertilization decreased NREac up to $9.5 \%$ compared with mineral fertilization in alkaline and near-neutral soils, while it significantly increased NREac by $15.3 \%$ in acidic soil. Under manure treatments, NREac in acidic soil significantly increased than that in alkaline and near-neutral soils. However, NREac in acidic soil significantly decreased by $12 \%$ and $11.2 \%$ under mineral fertilization compared with that in alkaline and near-neutral soils, respectively.

\section{Discussion}

\section{Effects of mineral $\mathrm{N}$ replacement by manure $\mathrm{N}$ on crop yield}

The cabbage yield under manure treatments was $17.7-146.8 \%$ higher than that under mineral fertilization, while such an effect was confirmed for maize only in acidic soil (Table 2). Manure application has been shown to increase both maize yield (Afreh et al., 2018; Wang et al., 2017) and rice yield over local farmers' $\mathrm{N}$ application practices (Zhang et al.,2018). Improved soil quality (e.g., high total $\mathrm{N}$ and organic $\mathrm{C}$ contents) as a consequence of manure application (Table 1) results in higher crop productivity compared with that under mineral fertilization (Liu et al., 2014). In contrast to cabbage, the maize yield did not increase under manure fertilization in alkaline and near-neutral soils. This is explained by the seasonal temperature difference between summer (maize) and winter (Chinese cabbage); higher temperatures enhance $\mathrm{N}$ release from all $\mathrm{N}$ resources, but lower temperatures slow $\mathrm{N}$ release (Agehara and Warncke, 2005). Under mineral fertilization, the crop yield decreased up to $39.7 \%$ in acidic soils compared with alkaline and near-neutral soils. In contrast, the crop yield under manure treatments increased by $4.8-18 \%$ in acidic soils compared with alkaline and near-neutral soils (Table 2). Such a discrepancy might be attributed to both the difference in the initial soil pH and the changes in pH after 10 years of $\mathrm{N}$ fertilization (2007-2017) (Table 1 and Fig. 2), causing soil acidification and aluminum toxicity (Liu et al., 2010). Soil acidification is a primary problem that is caused mainly by high N fertilizer application (Guo et al., 2010). Soil acidification causes the repression of plant cell elongation and cell division and ultimately affects crop yield (Valle et al., 2009). In contrast, management strategies improving soil pH result in higher $\mathrm{N}$ uptake (Afreh et al., 2018) and an increased crop yield.

\section{Effects of mineral $\mathrm{N}$ replacement by organic $\mathrm{N}$ on $\mathrm{N}$ uptake and NUE}

$\mathrm{N}$ uptake by Chinese cabbage and maize under combined organic-mineral fertilization increased up to $52.1 \%$ than that under mineral fertilization irrespective of the soil pH (Table 3). In general, higher aboveground biomass improves $\mathrm{N}$ uptake. Aboveground biomass is strongly correlated with $\mathrm{N}$ uptake (Abbast et al., 2010; Abbasi et al., 2012, 2013; Azeez et al., 2006). The yields of cabbage and maize under combined organic-mineral fertilization increased up to 129.5\% higher than those under mineral fertilization irrespective of the soil pH (Table 2), indicating a positive consequence of a higher $\mathrm{N}$ uptake under combined organic-mineral fertilization (Afreh et al., 2018). The $\mathrm{N}$ uptake of cabbage and maize under manure treatments was increased up to $14.3 \%$ in acidic soil compared to alkaline and near-neutral soils. In contrast, the $\mathrm{N}$ uptake of cabbage and maize under mineral fertilization was decreased up to $24.9 \%$ in acidic soil compared with alkaline and near-neutral soils (Table 3). Such a discrepancy might be attributed to both the difference in the initial soil pH and the changes in $\mathrm{pH}$ after 10 years of $\mathrm{N}$ fertilization (Table 1 and Fig. 2). After 10 years of vegetable-maize rotation, the pH change under manure treatments was increased by 2.03 units in acidic soil compared to alkaline and near-neutral soils. In contrast, the pH change under mineral fertilization in acidic soil was decreased by up to 1.47 units compared to alkaline soil (Table 1 and Fig. 2). Under mineral fertilization, the soil pH change had no difference between nearneutral and acidic soils, but the soil pH in near-neutral soil significantly higher than that in acidic soil in 2017 (Table 1). These findings clearly demonstrated 
the crucial role of an optimized soil pH (i.e., near neutral) in the improvement of $\mathrm{N}$ uptake by plants (Afreh et al., 2018). The lower pH inhibited soil microbial processes such as mineralization and nitrification, and then reducing $\mathrm{N}$ uptake by plants (Wang et al., 2013).

For Chinese cabbage, the higher AEN and PFP under manure treatments compared with mineral fertilization (Table 4) was attributed to high SOC, high total N, and slightly acidic to neutral pH (Table 1), both improving N uptake and enhancing NUE (Bouwman and Boumans., 2002). For maize, the higher AEN and PFP under manure treatments compared with mineral fertilization (Table 4) were only confirmed in acidic soil. This can be explained by 1 ) seasonal temperature differences between summer (maize) and winter (Chinese cabbage), which affect soil nutrient mineralization (Agehara and Warncke, 2005) and consequently crop yield and N uptake; and 2) the optimization of the pH by manure fertilization in acidic soil after 10 years of $\mathrm{N}$ fertilization (Table 1 and Fig. 2). Similarly, the higher AEN and PFP observed under manure treatments in acidic soil than in alkaline soil (Table 4) might have resulted from a manure-driven soil pH change (Table 1 and Fig. 2). Similarly, manure application has been shown to increase NUE in acidic soil under long-term maize-wheat cropping due to an increased soil pH (Duan et al., 2014) and consequently accelerates N uptake (Afreh et al., 2018). Moreover, the NPE under manure fertilization compared to mineral fertilization for Chinese cabbage and maize (Table 4), and these results are consistent with those of Sharma et al. (2021), who demonstrated that manure application increased the NPE.

\section{Effects of mineral $\mathrm{N}$ replacement by organic manure $\mathrm{N}$ on the $\mathrm{N}$ input-output balance}

High variability in NREac (Table 5) demonstrated its high sensitivity to soil properties and cropping systems (Liu et al., 2010). The N surplus under combined organic-mineral fertilization was $10.3-52.9 \%$ lower than that under mineral and manure fertilization, indicating that manure application decreased the risk of $\mathrm{N}$ loss (Wang et al., 2019; Huang et al., 2017). Under manure treatments, the $\mathrm{N}$ surplus in acidic soil was $15.4-20.7 \%$ lower than that in alkaline and nearneutral soils, demonstrating that manure treatments in acidic soil could decrease $\mathrm{N}$ losses. The reason was that the improvement of soil pH under manure treatments in acidic soil (Table 1 and Fig. 2) benefited for plant $\mathrm{N}$ uptake (Afreh et al., 2018), and then decreased soil $\mathrm{N}$ surplus. In contrast, the $\mathrm{N}$ surplus under mineral fertilization in acidic soil increased up to $50.8 \%$ compared with that in alkaline and near-neutral soils, indicating that mineral fertilization in acidic soil could increase the risk of environmental pollution. Such a discrepancy might be attributed to both the difference in the initial soil pH and the changes in pH after 10 years of $\mathrm{N}$ fertilization (2007-2017) (Table 1 and Fig. 2), soil acidification causes the repression of plant cell elongation and cell division and ultimately affects crop yield (Valle et al., 2009), and then increased soil $\mathrm{N}$ surplus.

In order to obtain higher crop yield, Chinese farmers applied excessive N in farmland (Liu et al., 2016; Zhang et al., 2016). Simultaneously, the crop yield response to applied $\mathrm{N}$, tends to decrease gradually when $\mathrm{N}$ application exceeds a certain threshold (Zhu and Chen, 2002). Moreover, applying excessive $\mathrm{N}$ will bring environmental severe consequences, such as air pollution, water eutrophication, and soil degradation (Chen et al., 2014; Cui et al., 2018; Zhang et al., 2017). However, the application of organic fertilizers in agriculture is a promising strategy not only to ensure a sustainable yield and high economic benefits but also improve soil structure and nutrient content (Pan et al., 2009; Ghosh et al., 2012; Mi et al., 2016). Therefore, we recommended combined organicmineral fertilization as the most efficient strategy, not only increases the crop yield, N uptake and NUE but also decreases the $\mathrm{N}$ surplus. In addition, applied manure fertilizers in acidic soil were significant.

\section{Conclusions}

Combined organic-mineral fertilization in alkaline, near-neutral, and acidic soils, as the most efficient strategy, not only increases the crop yield, $\mathrm{N}$ uptake and NUE but also decreases the $\mathrm{N}$ surplus. Manure fertilization in acidic soils, as a promising strategy, can increase crop yield and NUE by improving soil pH.

\section{Declarations}

The authors declare that they have no known competing financial interests or personal relationships that could have appeared to influence the work reported in this paper.

Acknowledgement This work was supported by China Agriculture Research System - Green Manure (No. CARS-22-G-13).

Author Contributions Jun Xie: Conceptualization, Methodology, Formal analysis, Visualization, Writing-original draft. Blagodatskaya Evgenia: Supervision, Investigation, Validation, Writing-review \& editing. Yu Zhang: Supervision. Jie Wang: Investigation, Supervision, Formal analysis. Yu Wan: Supervision. Xiaojun Shi: Conceptualization, Validation, Formal analysis, Writing-review \& editing, Project administration, Funding acquisition.

\section{References}

1. Abbasi MK, Tahir MM, Rahim N (2013) Effect of N fertilizer source and timing on yield and N use efficiency of rain fed maize (Zea mays L.) in KashmirPakistan. Geoderma 195:87-93

2. Abbasi MK, Tahir MM, Sadiq A, Iqbal M, Zafar M (2012) Yield and nitrogen use efficiency of rainfed maize response to splitting and nitrogen rates in Kashmir, Pakistan. Agron J 104:448-457

3. Abbast MK, Khaliq A, Shafiq M, Kazmi M, Ali I (2010) Comparative effectiveness of urea N, poultry manure and their combination in changing soil properties and maize productivity under rainfed conditions in Northeast Pakistan. Exp Agr 46:211-230

4. Afreh D, Zhang J, Guan DH, Liu KL, Song ZW, Zheng CY, Deng AX, Feng XM, Zhang X, Wu Y, Huang QR, Zhang WJ (2018) Long-term fertilization on nitrogen use efficiency and greenhouse gas emissions in a double maize cropping system in subtropical China. Soil Till Res 180:259-267

5. Agehara S, Warncke DD (2005) Soil moisture and temperature effects on nitrogen release from organic nitrogen sources. Soil Sci Soc Am J 69:18441855

Page $8 / 12$ 
6. Azeez JO, Adetunji MT, Lagoke STO (2006) Response of low-nitrogen tolerant maize genotypes to nitrogen application in a tropical Alfisol in northern Nigeria. Soil Till Res 91:181-185

7. Barbarick KA, Ippolito JA, McDaniel J, Hansen NC, Peterson GA (2012) Biosolids application to no-till dryland agroecosystems. Agric Ecosyst Environ 150:72-81

8. Benbi DK, Biswas CR (1997) Nitrogen balance and N recovery after 22 years of maize-wheat-cowpea cropping in a long-term experiment. Nutr Cycl Agroecosys 47:107-114

9. Bouwman AF, Boumans LJM, Batjes NH (2002) Modeling global annual $\mathrm{N}_{2} \mathrm{O}$ and $\mathrm{NO}$ emissions from fertilized fields. Global Biogeochem Cy $16: 1080$

10. Cao YS, Tian YH, Yin B, Zhu ZL (2013) Assessment of ammonia volatilization from paddy fields under crop management practices aimed to increase grain yield and $\mathrm{N}$ efficiency. Field Crop Res 147:23-31

11. Cassman KG, Dobermann A, Walters DT, Yang H (2003) Meeting cereal demand while protecting natural resources and improving environmental quality Annu Rev Env Resour 28:315-358

12. Chen X, Zhang F, Romheld V, Horlacher D, Schulz R, Boning-Zilkens M, Wang P, Claupein W (2006) Synchronizing N supply from soil and fertilizer and N demand of winter wheat by an improved N-min method. Nutr Cycl Agroecosys 74:91-98

13. Chen XM, Wo F, Chen C, Fang K (2010) Seasonal changes in the concentrations of nitrogen and phosphorus in farmland drainage and groundwater of the Taihu Lake region of China. Environ Monit Assess 169:159-168

14. Chen XP, Cui ZL, Fan MS, Vitousek P, Zhao M, Ma WQ, Wang ZL, Zhang WJ, Yan XY, Yang JC, Deng XP, Gao Q, Zhang Q, Guo SW, Ren J, Li SQ, Ye YL, Wang ZH, Huang JL, Tang QY, Sun YX, Peng XL, Zhang JW, He MR, Zhu YJ, Xue JQ, Wang GL, Wu L, An N, Wu LQ, Ma L, Zhang WF, Zhang FS (2014) Producing more grain with lower environmental costs. Nature 514:486-491

15. Chen YM, Zhao H, Xiao HJ, Xie TT, Qin S, Hu G (2021) Effect of nitrogen reduction combined with organic materials on crop yield, photosynthetic characteristics and product quality of corn-cabbage rotation system. Chinese J Appl Ecol. https://doi.org/10.13287/j.1001-9332.202112.015(in Chinese)

16. Cheng JH, Tang XY, Cui JF (2019) Effect of long-term manure slurry application on the occurrence of antibiotic resistance genes in arable purple soil (entisol). Sci Total Environ 647:853-861

17. Cociu Al (2012) Winter wheat yields and their stability in different crop rotation types and nitrogen fertilization regimes. Rom Agric Res 29:139-148

18. Cui ZL, Chen XP, Miao YX, Li F, Zhang FS, Li JL, Ye YL, Yang ZP, Zhang Q, Liu CS (2008) On-farm evaluation of winter wheat yield response to residual soil Nitrate-N in north China plain. Agron J 100:1527-1534

19. Cui ZL, Zhang HY, Chen XP, Zhang CC, Ma WQ, Huang CD, Zhang WF, Mi GH, Miao YX, Li XL, Gao Q, Yang JC, Wang ZH, Ye YL, Guo SW, Lu JW, Huang JL, Lv SH, Sun YX, Liu YY, Peng XL, Ren J, Li SQ, Deng XP, Shi XJ, Zhang Q, Yang ZP, Tang L, Wei CZ, Jia LL, Zhang JW, He MR, Tong YA, Tang Q, Zhong XH, Liu ZH, Cao N, Kou CL, Ying H, Yin YL, Jiao XQ, Zhang QS, Fan MS, Jiang RF, Zhang FS, Dou ZX (2018) Pursuing sustainable productivity with millions of smallholder farmers. Nature 555:363-366

20. Duan YH, Xu MG, Gao SD, Yang XY, Huang SM, Liu HB, Wang BR (2014) Nitrogen use efficiency in a wheat-corn cropping system from 15 years of manure and fertilizer applications. Field Crop Res 157:47-56

21. Galloway JN, Townsend AR, Erisman JW, Bekunda M, Cai ZC, Freney JR, Martinelli LA, Seitzinger SP, Sutton MA (2008) Transformation of the nitrogen cycle: recent trends, questions, and potential solutions. Science 320:889-892

22. Ghosh S, Wilson B, Ghoshal S, Senapati N, Mandal B (2012) Organic amendments influence soil quality and carbon sequestration in the Indo-Gangetic plains of India. Agr Ecosyst Environ 156:134-141

23. Guo JH, Liu XJ, Zhang Y, Shen JL, Han WX, Zhang WF, Christie P, Goulding KWT, Vitousek PM, Zhang FS (2010) Significant acidification in major Chinese croplands. Science 327:1008-1010

24. Hartmann TE, Yue SC, Schulz R, He XK, Chen XP, Zhang FS, Muller T (2015) Yield and N use efficiency of a maize-wheat cropping system as affected by different fertilizer management strategies in a farmer's field of the North China Plain. Field Crop Res 174:30-39

25. Huang T, Ju XT, Yang H (2017) Nitrate leaching in a winter wheat-summer maize rotation on a calcareous soil as affected by nitrogen and straw management. Sci Rep-UK 7:42247

26. Jin LB, Cui HY, Li B, Zhang JW, Dong ST, Liu P (2012) Effects of integrated agronomic management practices on yield and nitrogen efficiency of summer maize in North China. Field Crop Res 134:30-35

27. Li H, Yang XR, Weng BS, Su JQ, Nie SA, Glibert JA, Zhu YG (2016) The phenological stage of rice growth determines anaerobic ammonium oxidation activity in rhizosphere soil. Soil Biol Biochem 100:59-65

28. Liu C, Watanabe M, Wang QX (2008) Changes in nitrogen budgets and nitrogen use efficiency in the agroecosystems of the Changjiang River basin between 1980 and 2000. Nutr Cycl Agroecosys 80:19-37

29. Liu EK, Yan CR, Mei XR, He WQ, Bing SH, Ding LP, Liu Q, Liu SA, Fan TL (2014) Long-term effect of chemical fertilizer, straw, and manure on soil chemical and biological properties in northwest China. Geoderma 158:173-180

30. Liu J, Liu H, Huang SM, Yang XY, Wang BR, Li XY, Ma YB (2010) Nitrogen efficiency in long-term wheat maize cropping systems under diverse field sites in China. Field Crop Res 118:145-151

31. Liu XJ, Vitousek P, Chang YH, Zhang WF, Matson P, Zhang FS (2016) Evidence for a historic change occurring in China. Environ Sci Technol 50:505-506

32. Mi WH, Wu LH, Brookes PC, Liu YL, Zhang X, Yang X (2016) Changes in soil organic carbon fractions under integrated management systems in a lowproductivity paddy soil given different organic amendments and chemical fertilizers. Soil Till Res 163:64-70

33. Novoa R, Loomis RS (1981) Nitrogen and plant production. Plant Soil 58:177-204

Page 9/12 
34. Page AL, Millar RH, Keeney DR (1982) Methods of Soil Analysis: Part 2. American Society of Agronomy/Soil Science Society of America, Madison, WI, USA

35. Pan GX, Zhou P, Li ZP, Smith P, Li LQ, Qiu DS, Zhang XH, Xu XB, Shen SY, Chen XM (2009) Combined inorganic/organic fertilization enhances N efficiency and increases rice productivity through organic carbon accumulation in a rice paddy from the Tai Lake region, China. Agr Ecosyst Environ 131:274-280

36. Sharma S, Singh P, Choudhary OP, Neemisha (2021) Nitrogen and rice straw incorporation impact nitrogen use efficiency, soil nitrogen pools and enzyme activity in rice-wheat system in north-western India. Field Crop Res 266:108131

37. Valle SR, Pinochet D, Calderini DF (2009) Al toxicity effects on radiation interception and radiation use efficiency of Al-tolerant and Al-sensitive wheat cultivars under field conditions. Field Crop Res 114:343-350

38. Wang L, Zhao X, Gao JX, Butterly CR, Chen QH, Liu MQ, Yang YW, Xi YG, Xiao XJ (2019) Effects of fertilizer types on nitrogen and phosphorous loss from rice-wheat system in the Taihu Lake region of China. Agr Ecosyst Environ 285:106605

39. Wang LF, Du HC, Han ZQ, Zhang XL (2013) Nitrous oxide emissions from black soils with different pH. J Environ Sci 25:1071-1076

40. Wang XL, Ren YY, Zhang SQ, Chen YL, Wang N (2017) Applications of organic manure increased maize (Zea mays L.) yield and water productivity in a semi-arid region. Agr Water Manage 187:88-98

41. Xu JZ, Peng SZ, Yang SH, Wang WG (2012) Ammonia volatilization losses from a rice paddy with different irrigation and nitrogen managements. Agr Water Manage 104:184-192

42. Yang SH, Peng SZ, Xu JZ, Hou HJ, Gao XL (2013) Nitrogen loss from Paddy Field with different water and nitrogen managements in Taihu Lake Region of China. Commun Soil Sci Plan 44:2393-2407

43. Yang YC, Zhang M, Li YC, Fan XH, Geng YQ (2012) Controlled release urea improved nitrogen use efficiency, activities of leaf enzymes, and rice yield. Soil Sci Soc Am J 76:2307-2317

44. Yao Y, Zhang M, Tian YH, Zhao M, Zhang BW, Zhao M, Zeng K, Yin B (2017) Urea deep placement for minimizing $\mathrm{NH}_{3}$ loss in an intensive rice cropping system. Field Crop Res 218:254-266

45. Zhang M, Tian YH, Zhao M, Yin B, Zhu ZL (2017) The assessment of nitrate leaching in a rice-wheat rotation system using an improved agronomic practice aimed to increase rice crop yields. Agric Ecosyst Environ 241:100-109

46. Zhang M, Yao YL, Tian YH, Ceng K, Zhao M, Zhao M, Yin B (2018) Increasing yield and N use efficiency with organic fertilizer in Chinese intensive rice cropping systems. Field Crop Res 227:102-109

47. Zhang T, Chen AQ, Liu J, Liu HB, Lei BK, Zhai LM, Zhang D, Wang HY (2017) Cropping systems affect paddy soil organic carbon and total nitrogen stocks (in rice-garlic and rice-fava systems) in temperate region of southern China. Sci Total Environ 609:1640-1649

48. Zhang YL, Li CH, Wang YW, Hu YM, Christie P, Zhang JL, Li XL (2016) Maize yield and soil fertility with combined use of compost and inorganic fertilizers on a calcareous soil on the North China Plain. Soil Till Res 155:85-94

49. Zhu ZL, Chen DL (2002) Nitrogen fertilizer use in China - Contributions to food production, impacts on the environment and best management strategies. Nutr Cycl Agroecosys 63:117-127

\section{Figures}

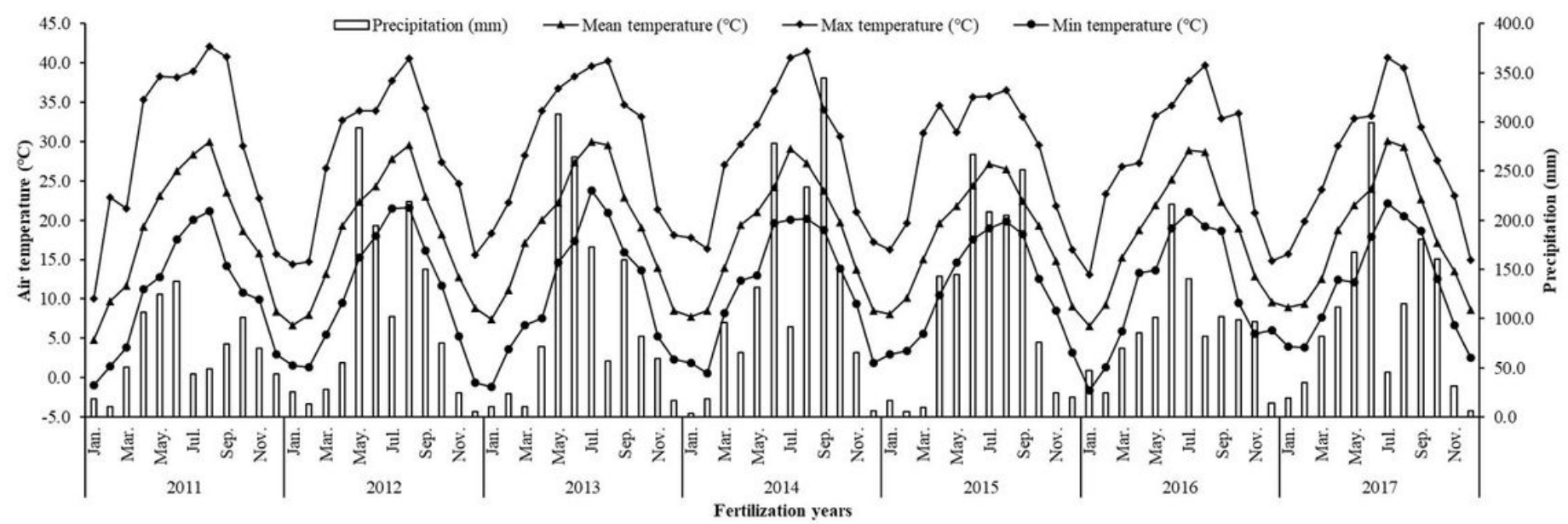

Figure 1

Monthly rainfall and air temperature during the study period (2011-2017). 

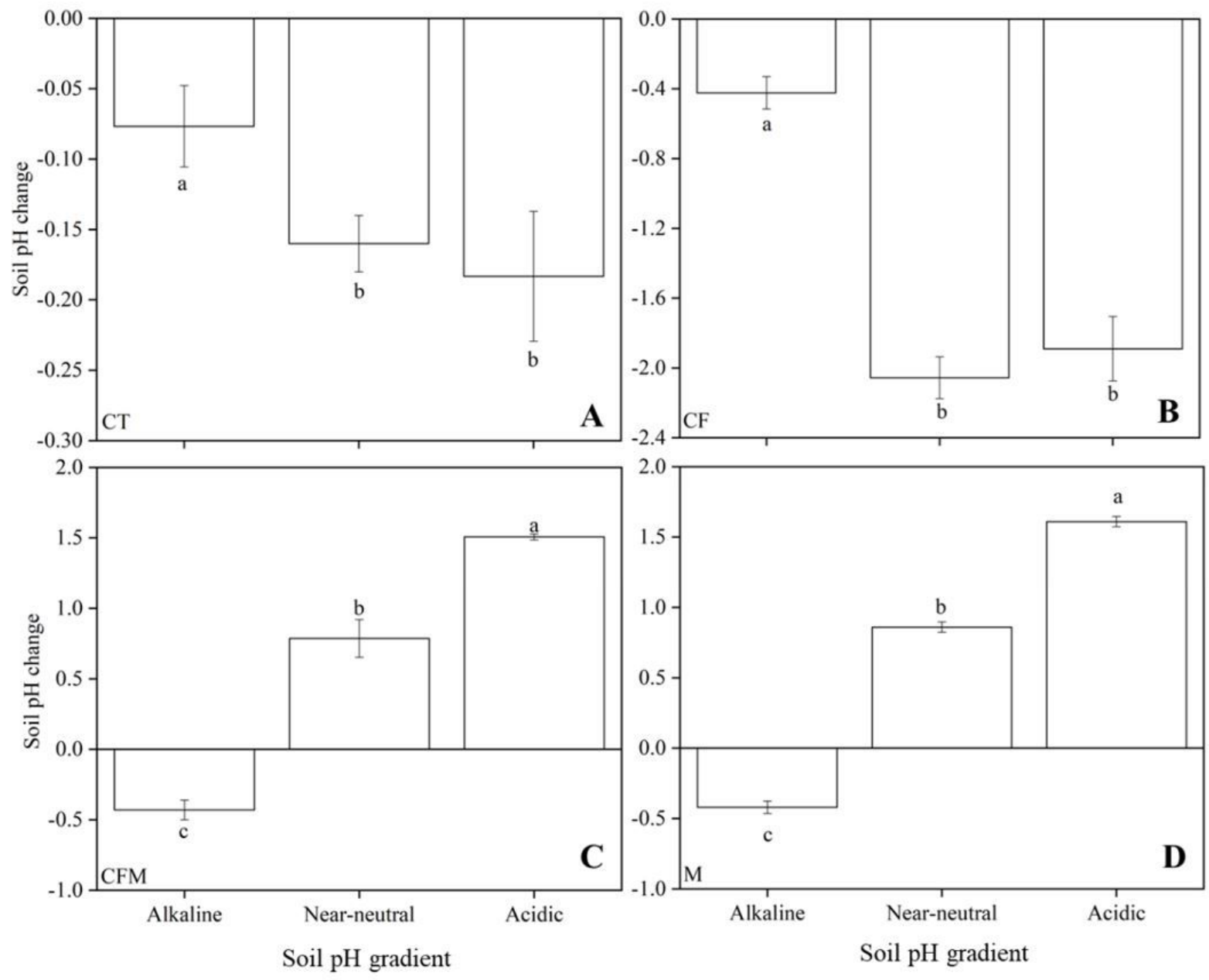

\section{Figure 2}

The change of soil pH in 2017 compared to their initial levels (2007). CT (no-fertilization control), CF (combined chemical N, P and K fertilization), CFM (50\% $\mathrm{CF}+50 \%$ chicken manure $\mathrm{N}$ ), $\mathrm{M}$ (chicken manure $\mathrm{N}$ ). A, soil pH change in $\mathrm{CT}$ under soil pH gradient. B, soil pH change in $\mathrm{CF}$ under soil pH gradient. C, soil pH change in CFM under soil pH gradient. $\mathrm{D}$, soil $\mathrm{pH}$ change in $\mathrm{M}$ under soil $\mathrm{pH}$ gradient. The data in the figures were mean values \pm standard deviation (SD) of three repeated.
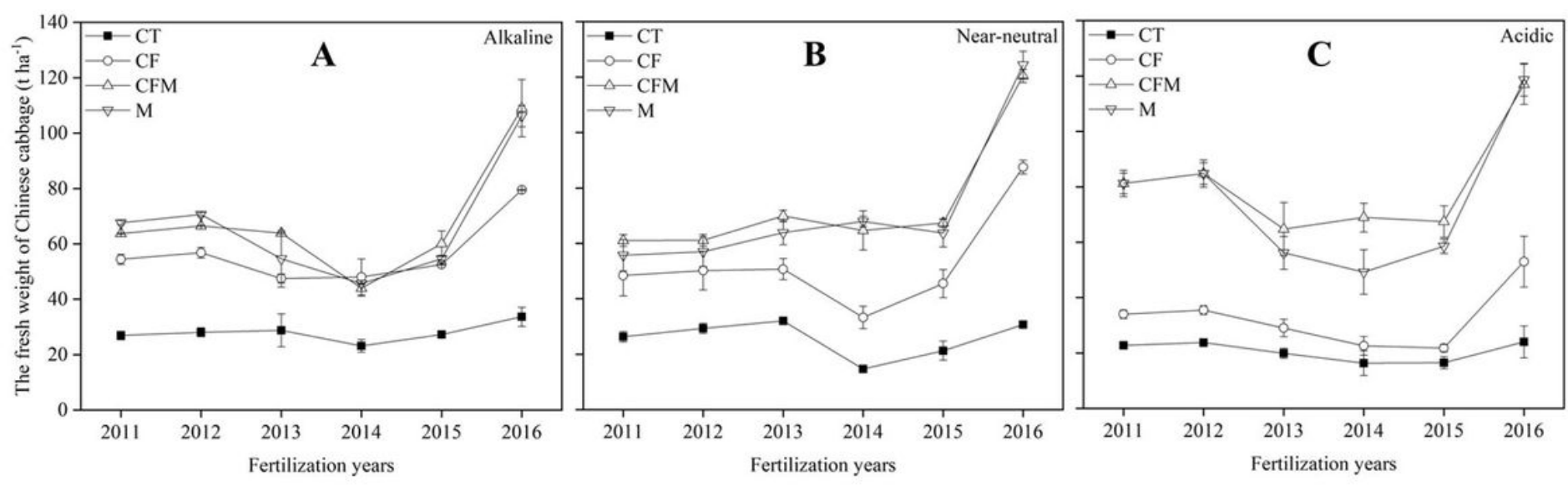

Figure 3 
The dynamic of the fresh weight of Chinese cabbage over six years under soil pH gradient. CT (no-fertilization control), CF (combined chemical $\mathrm{N}, \mathrm{P}$ and $\mathrm{K}$ fertilization), CFM (50\% CF + 50\% chicken manure N), M (chicken manure N). A, the dynamic of the fresh weight of Chinese cabbage in alkaline soil. B, the dynamic of the fresh weight of Chinese cabbage in near-neutral soil. $C$, the dynamic of the fresh weight of Chinese cabbage in acidic soil. The data in the figures were mean values \pm standard deviation (SD) of three repeated.
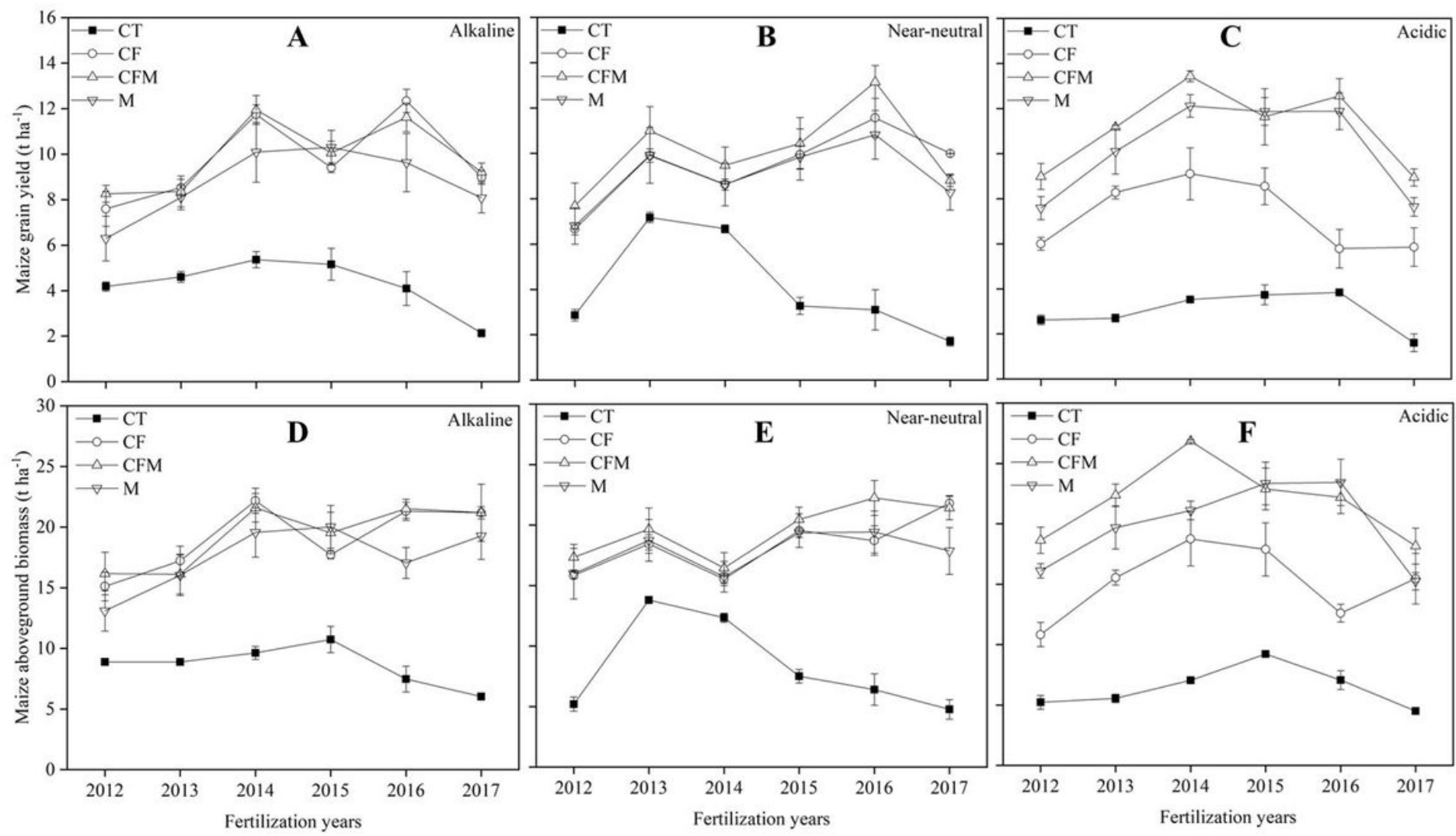

Figure 4

The dynamic of maize grain yield and aboveground biomass over six years under soil pH gradient. CT (no-fertilization control), $\mathrm{CF}$ (combined chemical $\mathrm{N}, \mathrm{P}$ and $\mathrm{K}$ fertilization), CFM ( $50 \% \mathrm{CF}+50 \%$ chicken manure $\mathrm{N}$ ), M (chicken manure $\mathrm{N}$ ). A, the dynamic of maize grain yield in alkaline soil. B, the dynamic of maize grain yield in near-neutral soil. $C$, the dynamic of maize grain yield in acidic soil. $D$, the dynamic of aboveground maize biomass in alkaline soil. $E$, the dynamic of maize aboveground biomass in near-neutral soil. F, the dynamic of maize aboveground biomass in acidic soil. The data in the figures were mean values \pm standard deviation (SD) of three repeated. 